\title{
CHEMICAL QUALITY OF TAP WATER VERSUS BOTTLED WATER: EVALUATION OF SOME HEAVY METALS AND ELEMENTS CONTENT OF DRINKING WATER IN DAKAHLIA GOVERNORATE - EGYPT
}

\author{
$\mathcal{B Y}$
}

\author{
Mona, A. El-Harouny; Sahar, A. El-Dakroory; \\ Sohayla, M. Attalla; Nermin A. Hasan* ; Ragia, Hegazy* \\ Departments of Forensic Medicine and Clinical Toxicology, \\ Faculty of Medicine, Mansoura and Benha University*, Egyp!
}

\begin{abstract}
Water is essential to sustain life, and a satisfactory safe supply must be made available to consumers. Many different chemicals may occur in drinking water. The problems associated with chemical constittents of drinking water arise primarily from their ability to cause significant human health risks after prolonged periods of exposure; of particular concern are contaminants that have cumulative toxic properties, such as heavy metals. This study was done to clarify concerns about chemical quality and safety of drinking tap water in Dakhlia governorate. For comparison, selected samples from three common commercial bottled water were analyzed. Atomic absorption Spectrometry technique was used to measure lead, cadmium, arsenic, mercury, zinc, selenium, calcium, magnesium and sodium in 65 samples of tap water and nine samples of bottled water. The mean concentrations of the metals in drinking water obtained in this study were within the acceptable levels of the World Health Organization (WHO,2004) guidelines and lower than maximum contaminated levels (MCL) established by the United States Environmental Protection Agency (USEPA,2004). Tap water showed slightly higher levels of lead, arsenic cadmium, zinc, and selenilum.
\end{abstract}

Keywards: tap water, botteled water, heavy metals, chemical quality, atomic absorption.

\section{INTRODUCTION}

Safe drinking water is a basic need for human development, health and wellbeing, it is an internationally accepted human right (WHO, 2001). Chemical contaminants of drinking water are often considered a lower priority than microbial contaminants, as adverse health effects from chemical contaminants are generally associated with long-term exposures, whereas the effects from microbial contaminants are usually immediate. Nonetheless, chemicals in water supplies can cause very serious problems (WHO, 2007).

The abundance of toxic chemicals in drinking water may cause adverse effect 
on the human health such as cancer and chronic illness (IKem et al., 2002). Epidemiological studies have indicated a strong association between the occurrence of several diseases in humans, particularly cardiovascular diseases, kidney-related disorders, neurocognitive effects and various forms of cancer and the presence of many metals such as cadmium, mercury and lead (Al -Saleh and Al-Doush, 1998).

Water may contain toxic metals like mercury, lead, cadmium, arsenic and selenium. These metals can cause acute or chronic poisoning and should be eliminated from drinking water, if possible. Several metal ions such as sodium, calcium and magnesium are essential to sustain biological life. Other additional metals are also essential for optimal growth, development and reproduction like zinc which is in small enough quantities to be considered trace element. Trace metals function mostly as catalysts for enzymatic activity in human bodies; however, their accumulation in the human body cause harmful effects (Tayyeb et al., 2004).

So, this study aims to assess drinking water chemically to determine whether it is capable of meeting the health-based targets and as it is neither physically nor economically feasible to test for all chemical constituents in drinking water, monitoring efforts were directed at significant parameters.

\section{MATERIAL AND METHODS}

\section{Sampling:}

Water samples were randomly collected from private residencies at different 13 locations "districts" of Dakhlia Governorate (L1: El-Mansoura, L2: Talkha, L3: Bilqas, L4: Dekernis, L5: Sherbin, L6: ElSinbillawin, L7: Minyat El-Nasr, L8: ElManzala, L9: El-Gamalia, L10: Mit-Salsil, L11: TemiEl-Amdid, L12 : Aga, L13: Mit Ghamr). Of each location, five water sampling were taken from different houses. Chemical studies were performed for 65 household tap water samples collected from November to December 2006. These samples represent indoor tap water after passing in the plumbing of each building.

Tap water was kept in sealed glass bottles, refrigerated and transferred to the laboratory for analysis. All samples were analyzed within 7 days from the time of collection. No preservatives were added to any of the collected samples.

Three different brands of the most popular commercial bottled water; Aquafina, Baraka and Shewepes were purchased from local markets in Dakhlia. Samples from three bottles of the $1.5 \mathrm{~L}$ size were analyzed for each brand. All brands of bottled water are sold in sealed plastic botthes and were kept in refrigerator at $4^{\circ} \mathrm{C}$ until the time of analysis. 
Elemental analysis:

Analysis of the studied heavy metals and trace elements [lead $(\mathrm{Pb})$; cadmium:

(Cd); arsenic (As); mercury (Hg); sodium (Na); calcium (Ca); magnesium (Mg); zinc ( $\mathrm{Zn}$ ) and selenium (Se)] was done by Perkin Elmer 2380 Atomic Absorption Spectrophotometer. Samples were prepared according to APHA method, (1992). Instrument start- up and optimization were carried out as detailed in the operating manual. The source of the flame was an air- acetylene mixture. Hydride generation method was used for $\mathrm{Hg}$, As and Se. Selected wave length for each element detection was showed in table (A).Working standard solutions were prepared by appropriate dilution of stock solutions. Each measurement was made in triplicate and the mean of the three values was taken.

Preparation of standards and samples was carried out under clean conditions using deionized water. All chemicals and reagents used were of ultra pure reagent grade (BDH laboratory reagents, Ltd Poole England). All glassware and plasticware were washed three times with deionized water, and then soaked in $20 \%$ nitric acid overnight. After soaking the glasswares were rinsed three times with deionized water and dried. Quality assurance was achieved by measuring blank test solutions.

Quality control was performed according to the specified conditions of the specific USEPA method, (2004) by analysis of laboratory reagent blanks, fortified blanks and samples as a continuing check of performance. Rinse blanks and five calibrated standard solutions of all monitored analytes were used at part per million (ppm) or part per billion ( $p p b$ ) concentration ranges for the different analytes.

Table (A): Selected wavelengths for the tested elements.

\begin{tabular}{|l|c|c|c|c|c|c|c|c|c|}
\hline Elements & $\mathbf{P b}$ & $\mathrm{Cd}$ & $\mathrm{As}$ & $\mathrm{Hg}$ & $\mathrm{Na}$ & $\mathrm{Ca}$ & $\mathbf{M g}$ & $\mathrm{Zn}$ & $\mathrm{Se}$ \\
\hline Wavelength (nm) & 217 & 228.8 & 193.7 & 253.7 & 589 & 422.7 & 285.2 & 213.9 & 196 \\
\hline
\end{tabular}




\section{RESULTS}

Elemental analysis of water samples was carried out using Perkin Elmer 2380 Atomic Absorption Spectrophotometer. The results are shown in tables $(1,2)$ and figures (1-9). Elements including sodium, calcium and magnesium were found as ppm and reported as $\mathrm{mg} / \mathrm{L}$, other elements were found as $\mathrm{ppb}$ and reported as $\mu \mathrm{g} / \mathrm{L}$.

Mean concentrations of heavy metals and trace elements in drinking tap water from the studied locations were shown in table (1). All concentrations were below the internationally recognized water quality standards.

The mean concentrations of elements analysis in three common commercial bottled water brands were shown in table (2). They were also within the accepted international recommended levels. Lead concentration in tap water was higher $(0.58 \pm 0.23 \mu \mathrm{g} / \mathrm{L})$ than in bottled water $(0.2$ $\pm 0.01 \mu \mathrm{g} / \mathrm{L}, 0.17 \pm 0.005 \mu \mathrm{g} / \mathrm{L}, 0.14 \pm 0.002$ $\mu \mathrm{g} / \mathrm{L}$ for Shewepes, Baraka and Aquafina respectively) (Figure 1).

Cadmium concentration in tap water was higher $(0.45 \pm 0.16 \mu \mathrm{g} / \mathrm{L})$ than bottled water. Acquafina brand contains higher cadmium $(0.4 \pm 0.002 \mu \mathrm{g} / \mathrm{L})$ than the other two brands $(0.2 \pm 0.09 \mu \mathrm{g} / \mathrm{L}$ for Shewepes, $0.2 \pm 0.005 \mu \mathrm{g} / \mathrm{L}$ for Baraka) (Figure 1).
Arsenic level was higher in tap water $(0.29 \pm 0.16 \mu \mathrm{g} / \mathrm{L})$ than bottled water $(0.05 \pm 0.001 \mu \mathrm{g} / \mathrm{L}, \quad 0.04 \pm 0.001 \mu \mathrm{g} / \mathrm{L}$, $0.03 \pm 0.001 \mu \mathrm{g} / \mathrm{L}$ for Shewepes, Baraka and Aquafina respectively) (Figure 1).

Mercury concentration was higher in bottled water than tap water $(0.05 \pm 0.01$ $\mu \mathrm{g} / \mathrm{L})$; Shewepes contained the highest level $(0.18 \pm 0.004 \mu \mathrm{g} / \mathrm{L})$ followed by Baraka $(0.16 \pm 0.005 \mu \mathrm{g} / \mathrm{L})$ then Aquafina $(0.13 \pm 0.002 \mu \mathrm{g} / \mathrm{L})$ (Figure 1).

Zinc concentration was higher in tap water $(5.9 \pm 2.3 \mu \mathrm{g} / \mathrm{L})$ than bottled water $(4 \pm 0.5 \mu \mathrm{g} / \mathrm{L}, 3.2 \pm 0.07 \mu \mathrm{g} / \mathrm{L}, 2 \pm 0.003 \mu \mathrm{g} / \mathrm{L}$ for Shewepes, Baraka and Aquafina respectively) figure (2). Selenium was slightly higher in tap water $(1.6 \pm 0.21 \mu \mathrm{g} / \mathrm{L})$ than bottled water $(1.5 \pm 0.08 \mu \mathrm{g} / \mathrm{L}$, $1.4 \pm 0.03 \mu \mathrm{g} / \mathrm{L}, 1.2 \pm 0.03 \mu \mathrm{g} / \mathrm{L}$ for Shewepes, Baraka and Aquafina respectively) (Figure 2).

Sodium concentration in Shewepes $(13.9 \pm 2.5 \mathrm{mg} / \mathrm{L})$ and Baraka $(13.7 \pm 2.1$ $\mathrm{mg} / \mathrm{L})$ were higher than Aquafina brand $(5.9 \pm 0.6 \mathrm{mg} / \mathrm{L})$ and tap water $(8.41 \pm 0.39 \mathrm{mg} / \mathrm{L})$ (Figure 3). Calcium concentration was the highest in Baraka bottled water $(17.7 \pm 3.2 \mathrm{mg} / \mathrm{L})$, followed by tap water $(11.8 \pm 1.29 \mathrm{mg} / \mathrm{L})$, Shewepes $(8.3 \pm 1.5 \mathrm{mg} / \mathrm{L})$ and the least level was in Aquafina brand $(2.3 \pm 0.2 \mathrm{mg} / \mathrm{L})$ (Figure 3). Magnesium concentration in bottled water was higher $(15.2 \pm 3.6 \mathrm{mg} /$ 
L, $13.7 \pm 2.1 \mathrm{mg} / \mathrm{L}, 12.6 \pm 2.4 \mathrm{mg} / \mathrm{L}$ for Bara$\mathrm{ka}$, Shewepes and Aquafina respectively) than tap water $(10.4 \pm 0.93 \mathrm{mg} / \mathrm{L}$ ) (Figure 3).

\section{DISCUSSION}

Water quality is an important aspect in human health, as the majority of diseases that cause morbidity and mortality in population are water related (Shayo et al., 2007). Many different chemicals may occur in drinking water; however, only a few are important in any given circumstance. Of particular importance are adverse health outcomes relating to chemical constituents of drinkingwater arising primarily from prolonged exposure. It is extremely unlikely that all the chemicals included in the WHO guidelines for drinking-water quality (WHO, 2004a) will be present in a drinking-water supply system. Consequently, it is important that countries identify those chemicals of concern according to local circumstances.

So, this study aim to evaluate some chemicals of health concern in drinking tap water in our locality and compare between these random samples and commonly used bottled water in concern of their chemical quality.

Lead is a cumulative general poison; the fetus and pregnant women, infants

Mansourn J. Forensic Med. Clin. Toxicol. and children up to 6 years of age are the most susceptible to its adverse health effects. Its effects on the central nervous system can be particularly serious (WHO, 2003a). The almost universal use of lead is plumbing fittings and as solder in waterdistribution systems. Lead pipes may be used in old distribution systems and plumbing (Quinn and Sherlock, 1990). Corrosion of plumbing systems is an important source of excessive lead in drinking-water, so lead levels in water should be measured at the tap, rather than at the drinking-water source, when estimating human exposure (WHO, 2003a).

The results of the present study showed that mean lead level in tap water is 0.58 $\mu \mathrm{g} / \mathrm{L} \pm 0.23$.It is below the recommended levels of WHO guideline value $(10 \mu \mathrm{g} / \mathrm{L})$ and USEPA $(5 \mu \mathrm{g} / \mathrm{L})$. It was higher than total bottled water mean: $0.17 \mu \mathrm{g} / \mathrm{L} \pm 0.03$. In agreement with the present results, Saleh et al. (2001) found that the lead levels in tap water from Cairo and Giza were within recommended WHO level. Siwa bottled water contained relatively higher level of lead than other bottled water but still below the recommended level. Mohamed and Osman (1998) also concluded that the drinking-water mean lead concentration in Greater Cairo was below the international standards. In the state of $\mathrm{Ku}$ wait, Al-Fraij et al. (1999) revealed the same results; lead in drinking tap water

Vol. XVI, No.2, July 2008 
and tested types of bottled water complied with WHO guidelines. In Saudi Arabia, Tayyeb et al. (2004) analyzed lead in drinking galloned water and bottled water which also was within the maximum permissible WHO level.

Contamination of drinking-water by cadmium may occur as a result of its presence as an impurity in the zinc of galvanized pipes or cadmium-containing solders in fittings, water heaters and taps. With chronic oral exposure, the kidney appears to be the most sensitive organ. Cadmium affects the resorption function of the proximal tubules; the first symptom is tubular proteinuria. Disturbances in renal handling of phosphorus and calcium may cause resorption of minerals from bone, which can result in the development of kidney stones and osteomalacia (WHO, $2004 \mathrm{~b}$ ). It is associated also with hypertension and can cause mutations (Saleh et al., 2001).

Mean cadmium level in tap water in this study $(0.45 \pm 0.16 \mu \mathrm{g} / \mathrm{L})$ was slightly higher than in bottled water $(0.27 \mu \mathrm{g} /$ $\mathrm{L} \pm 0.11)$.They are within the accepted recommended levels by WHO $(3 \mu \mathrm{g} / \mathrm{L})$ and USEPA $(5 \mu \mathrm{g} / \mathrm{L})$. This result coincides with those of Mohamed and Osman (1998) in Greater Cairo, Al Fraij et al. (1999)in Kuwait, Saleh et al. (2001) in Cairo and Giza and Tayyeb et al. (2004) in Saudi Arabia.
Arsenic is introduced into drinkingwater sources primarily through the dissolution of naturally occurring minerals and ores. There are number of regions where arsenic may be present in drinking-water sources, particularly groundwater at elevated concentrations. $1 t$ is one of the few substances shown to cause cancer in humans through consumption of drinkingwater. There is overwhelming evidence from epidemiological studies that consumption of elevated levels of arsenic through drinking-water is causally related to the development of cancer at several sites, particularly skin, bladder and lung (WHO, 2003b).

Mean arsenic level in tap drinking water in this study $(0.29 \mu \mathrm{g} / \mathrm{L} \pm 0.16)$ was higher than bottled water $(0.04 \mu \mathrm{g} / \mathrm{L} \pm 0.008)$. They are below the recommended WHO $(10 \mu \mathrm{g} / \mathrm{L})$ and USEPA $(50 \mu \mathrm{g} / \mathrm{L})$ levels. In consistent with these results, Al Fraij et al., (1999) in Kuwait revealed that arsenic level in drinking and bottled water was below WHO and USEPA recommended levels. In contrast, Saleh et al. (2001) could not estimate arsenic in tap drinking water in Cairo and Giza by inductively coupled plasma mass spectrometry (ICP / MS) because it was below the instrument detection limit which is $(0.06 \mu \mathrm{g} / \mathrm{L})$.

As regards, naturally occurring mercury level in ground and surface water, it was less than $0.5 \mu \mathrm{g} / \mathrm{L}$, although local 
mineral deposits may produce higher level in groundwater (Saleh et al., 2001). The toxic effects of inorganic mercury compounds are seen mainly in the kidney. Methyl mercury affects mainly the central nervous system (WHO, 2003c).

In the present study, mean mercury level in tap water $(0.05 \mu \mathrm{g} / \mathrm{L} \pm 0.01)$ was slightly lower than its mean in bottled water $(0.16 \mu \mathrm{g} / \mathrm{L} \pm 0.02)$. The highest level was in Shewepes bottled water $(0.18 \mu \mathrm{g} /$

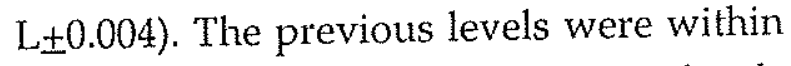
recommended WHO and USEPA levels (1ug/L and $2 \mathrm{ug} / \mathrm{L}$ respectively).

Zinc is considered an essential trace metal which functions as catalyst for enzymatic activity in human bodies. Drinking water contains this trace metal in very small quantities which may reduce the possibility of its deficiency in the diet. However, its accumulation in the human body cause harmful effects such as acceleration of anemic conditions (Tayyeb et al., 2004). In this study, tap water mean $\mathrm{Zn}$ concentration (5.9 ug $/ \mathrm{L} \pm 2.3$ ) was higher than its mean in bottled water $(2.98$ $\mathrm{ug} / \mathrm{L} \pm 1.05)$, both are within the recommended USEPA level(5000ug/L) for good health. Virkutyte and Sillanpaa, (2006) explained the differences in $\mathrm{Zn}$ concentrations by the specific hydrogeology and hydrochemistry of the sampling points. $\mathrm{Zn}$ concentration decreases in low salinity regions.
Selenium is an essential element for humans, the toxic effects of its long term exposure are manifested in nails, hair and liver (WHO, 2003d). Mean selenium concentration in tap water $(1.6 \mathrm{ug} / \mathrm{L} \pm 0.21)$ was slightly higher than its mean in botthed water $(1.37 \mathrm{ug} / 1 \pm 0.14)$.They are below WHO and USEPA recommended levels (10ug/L and 50ug/L respectively).

As regards, mean cations concentration : Sodium (Na), Calcium (Ca) and Magnesium $(\mathrm{Mg})$ in the tap water samples were $(8.4 \mathrm{mg} / \mathrm{L} \pm 0.39)$, (11.8 mg/ $\mathrm{L} \pm 1.29)$ and $(10.4 \mathrm{mg} / \mathrm{L} \pm 0.9)$ respectively. In the bottled water samples, their means were $(11.17 \mathrm{mg} / \mathrm{L} \pm 4.29)$, (9.4 mg/ $\mathrm{L} \pm 6.95)$ and $(13.6 \mathrm{mg} / \mathrm{L} \pm 2.63)$ respectively. Baraka bottled water contains the highest level of these cations; $(13.7 \pm 2.1$ for $\mathrm{Na}$, 17.7 \pm 3.2 for $\mathrm{Ca}$ and $15.2 \pm 3.6$ for $\mathrm{Mg}$ ). The lowest range was in Aquafina brand (5.9 \pm 0.6 for $\mathrm{Na}, 2.3 \pm 0.2$ for $\mathrm{Ca}$ and $12.6 \pm 2.4$ for $\mathrm{Mg}$ ).

Sodium concentration of bottled water was higher in Shewepes and Baraka than tap water. Sodium may affect the taste of drinking water at levels above $200 \mathrm{mg} / \mathrm{L}$ (Saleh et al., 2001). Also, Mg concentration in bottled water was higher than tap water; Baraka contained the highest level followed by Shewepes then Aquafina. No upper limit has been set for this metal in drinking water. Hardness in water is caused by dissolved calcium, and to a 
lesser extent magnesium (WHO, 2003e). Water containing less than $60 \mathrm{ppm}(60$ $\mathrm{mg} / \mathrm{L}$ ) of $\mathrm{Ca}$ is considered as soft water (Saleh et al., 2001). Soft water has a corrosive effect to water pipes. A number of ecological and analytical epidemiological studies have shown a statistically significant inverse relationship between hardness of drinking water and cardiovascular disease (WHO, 2003e). On the other side, water hardness may protect against disease (Derry et al., 1990). None of water samples in this study is considered as hard water. Tap water mean Ca concentration (11.8 mg/ L \pm 1.29 ) was higher than its level in Shewepes and Aquafina. Baraka brand contains higher $\mathrm{Ca}$ level than other brands and tap water. However, all are categorized as soft water. No healthbased guideline value is proposed for hardness (WHO, 2003e).

In conclusion, this study showed that the concentration of all analyzed elements in both tap and bottled water were within the WHO,(2004a) concentration guidelines and below the maximum contaminant levels (MCL) established by the USEPA, (2004). Tap water contained higher levels of lead, cadmium, arsenic, zinc and selenium. It also contained higher calcium level than Shewepes and Acquafina bottled water brands. All brands of bottled water contained higher levels of mercury and magnesium. Sodium concentration was higher in Shewepes and Bara- ka bottled water brands than tap water. Generally, Shewepes and Baraka bottled water contained higher levels of studied elements than Aquafina except cadmium. Some of detected metals are present in tap water in higher levels than bottled water as a result of their dissolution from either natural sources or from household plumbing systems, such as pipes, solder, fittings or the service connections to homes. The amount of dissolved metal from the plumbing system depends on several factors, including $\mathrm{pH}$, temperature, water hardness and standing time of the water. From a general point of view, some of these metals show accumulative toxic effects and may be carcinogenic. However, bottled water was found not better than tap water from the health point of view.

This study provides guidance to assist water supply utilities in collaboration with public health authorities and toxicologists, to identify those chemicals that are likely to be present in an individual water supply, and may represent a potential public health risk from long-term exposure. Appropriate monitoring programes should be established to ensure that the chemical quality of drinking water remains within acceptable national standards and to maintain water safety for public use. Reduction of metals which have cumulative toxic hazards in drinking water is a necessity. 
Table (1): Mean concentrations of heavy metals and trace elements in the studied drinking tap water.

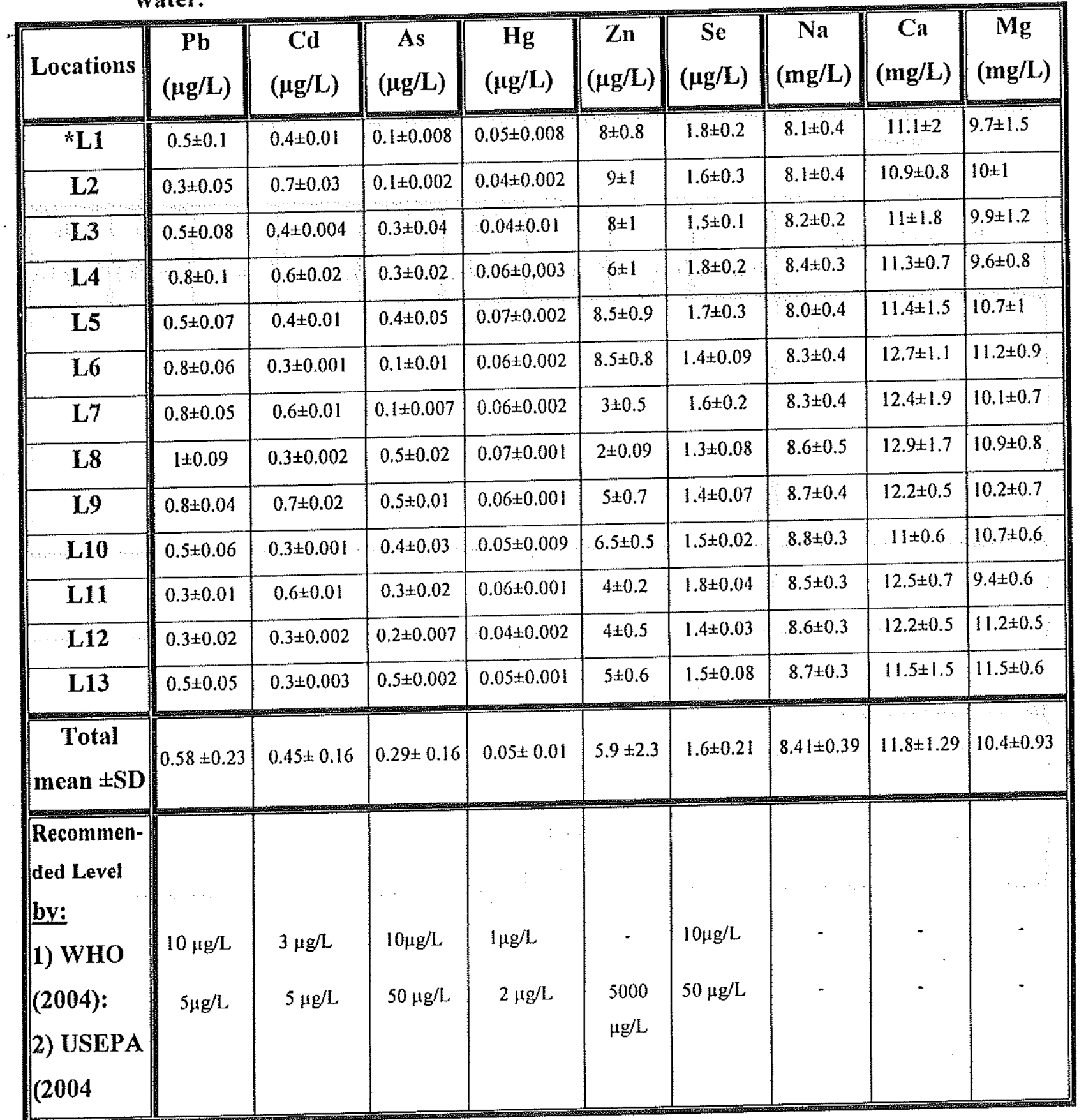

*L: Location.

Mansoura J. Forensic Med. Clin. Toxicol. 
Table (2): Mean concentrations of the studied heavy metals and trace elements in bottled water.

\begin{tabular}{|c|c|c|c|c|c|c|c|c|c|}
\hline Type (brand) & $\begin{array}{c}\mathbf{P b} \\
(\mu \mathrm{g} / \mathrm{L})\end{array}$ & $\begin{array}{c}\mathrm{Cd} \\
(\mu \mathrm{g} / \mathrm{L})\end{array}$ & $\begin{array}{c}\mathrm{As} \\
(\mu \mathrm{g} / \mathrm{L})\end{array}$ & $\begin{array}{c}\mathrm{Hg} \\
(\mu \mathrm{g} / \mathrm{L})\end{array}$ & $\begin{array}{c}\mathrm{Zn} \\
(\mu \mathrm{g} / \mathrm{L})\end{array}$ & $\begin{array}{c}\text { Se } \\
(\mu \mathrm{g} / \mathrm{L})\end{array}$ & $\begin{array}{c}\mathrm{Na} \\
(\mathrm{mg} / \mathrm{L})\end{array}$ & $\begin{array}{c}\mathrm{Ca} \\
\vdots \\
(\mathrm{mg} / \mathrm{L})\end{array}$ & $\begin{array}{c}\mathrm{Mg} \\
(\mathrm{mg} / \mathrm{L})\end{array}$ \\
\hline Shewepes: Mean \pm SD & $\begin{array}{c}0.2 \\
\pm 0.01\end{array}$ & $\begin{array}{c}0.2 \\
\pm 0.09\end{array}$ & $\begin{array}{c}0.05 \pm 0 . \\
001\end{array}$ & $\begin{array}{c}0.18 \\
\pm 0.004\end{array}$ & $\begin{array}{c}4 \\
\pm 0.5\end{array}$ & $\begin{array}{c}1.5 \\
\pm 0.08\end{array}$ & $\begin{array}{l}13.9 \\
\pm 2.5\end{array}$ & $\begin{array}{r}8.3 \\
\pm 1.5\end{array}$ & $\begin{array}{l}13.7 \\
\pm 2.1\end{array}$ \\
\hline Domal & 0.17 & 0.2 & 0.04 & 0.16 & 3.2 & 1.4 & 13.7 & 17.7 & 15.2 \\
\hline Däана & \pm 0.005 & \pm 0.005 & \pm 0.001 & \pm 0.005 & \pm 0.07 & \pm 0.03 & \pm 2.1 & \pm 3.2 & \pm 3.6 \\
\hline 40 & 0.14 & 0.4 & 0.03 & 0.13 & 2 & 1.2 & 5.9 & 2.3 & 12.6 \\
\hline 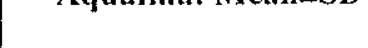 & \pm 0.002 & \pm 0.002 & \pm 0.001 & \pm 0.002 & \pm 0.003 & \pm 0.03 & \pm 0.6 & \pm 0.2 & \pm 2.4 \\
\hline Tatel & 0.17 & 0.27 & 0.04 & 0.16 & 2.98 & 1.37 & 11.17 & 9.43 & 13.61 \\
\hline 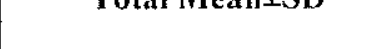 & \pm 0.03 & \pm 0.11 & \pm 0.008 & \pm 0.02 & \pm 1.05 & \pm 0.14 & \pm 4.29 & \pm 6.95 & \pm 2.63 \\
\hline \multicolumn{10}{|l|}{ Recommended level by: } \\
\hline \multirow{2}{*}{$\begin{array}{l}\text { 1) WHO(2004): } \\
\text { 2) USEPA(2004): }\end{array}$} & \multirow{2}{*}{$\begin{array}{l}10 \mu \mathrm{g} / \mathrm{L} \\
5 \mu \mathrm{g} / \mathrm{L}\end{array}$} & \multirow{2}{*}{$\begin{array}{l}3 \mu \mathrm{g} / \mathrm{L} \\
5 \mu \mathrm{g} / \mathrm{L}\end{array}$} & \multirow{2}{*}{$\begin{array}{l}10 \mu \mathrm{g} / \mathrm{L} \\
5 \mu \mathrm{g} / \mathrm{L}\end{array}$} & \multirow{2}{*}{$\begin{array}{l}1 \mu \mathrm{g} / \mathrm{L} \\
2 \mu \mathrm{g} / \mathrm{L}\end{array}$} & - & $10 \mu \mathrm{g} / \mathrm{L}$ & - & - & - \\
\hline & & & & & $\begin{array}{l}5000 \\
\mu \mathrm{g} / \mathrm{L}\end{array}$ & $50 \mu \mathrm{g} / \mathrm{L}$ & - & - & - \\
\hline
\end{tabular}




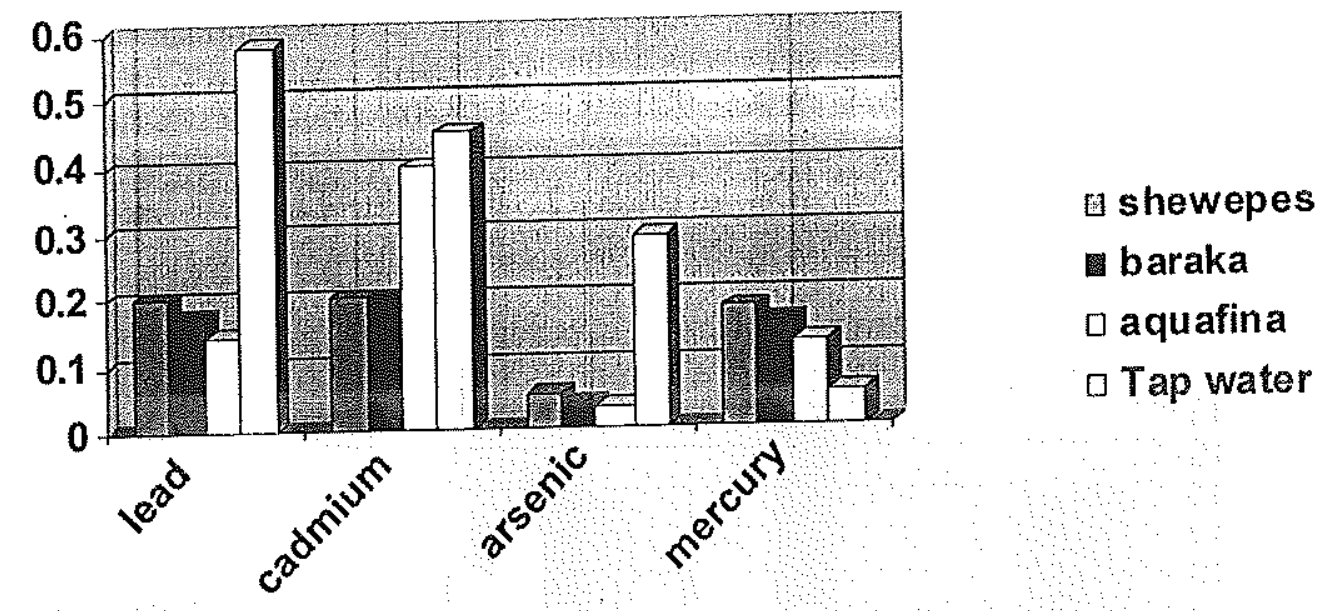

Fig. (1): Concentrations of lead, cadmium, arsenic and mercury in the studied tap water and bottled water (shewepes, baraka and aquafina) in ug $/ \mathrm{L}$.

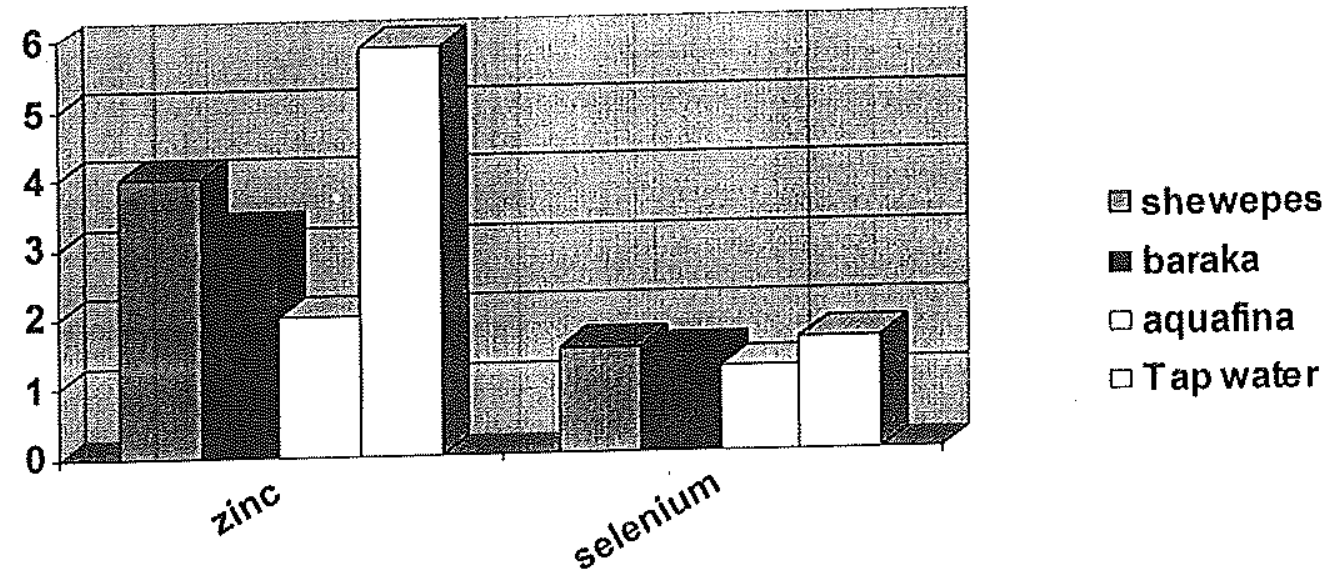

Fig. (2): Concentrations of zinc and selenium in the studied tap water and bottled water (shewepes, baraka and aquafina) in ug $/ \mathrm{L}$. 


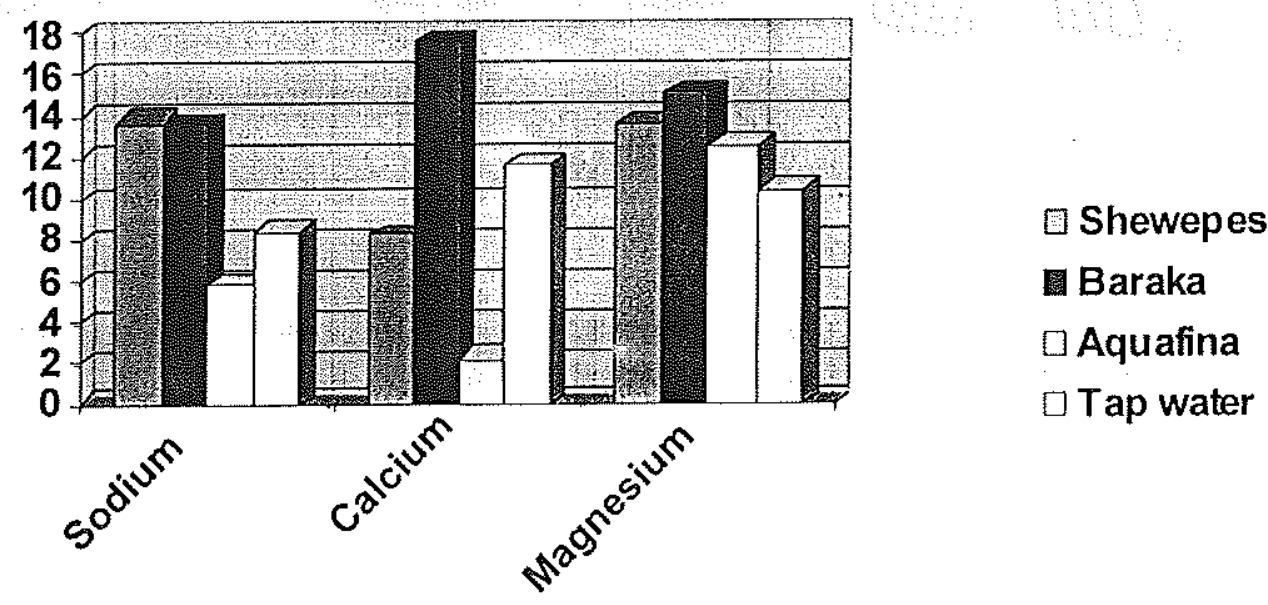

Fig. (3): Concentrations of sodium, calcium and magnesium in the studied tap water and bottled water (shewepes, baraka and aquafina) in $\mathrm{mg} / \mathrm{L}$. 


\section{REFERENCES}

Al- Fraij, K. M.; Abd EL Aleem, M. K. "and Al- Ajmy, H. (1999) : "Comparative study of potable and mineral waters available in the state of Kuwait". Desalination, 123: $253-264$.

Al -Saleh, I. and Al-Doush, I. (1998): "Survey of trace elements in household and bottled drinking water samples collected in Riyadh, Saudi Arabia". The Science of the Total Environment, 216:181 192.

APHA (American Public Health Association) (1992) : Standard Methods For The Examination of Water and Wastewater. $18^{\text {th }}$ edition, Washington, D.C.

Derry, C. W.; Bourne, D. E and Sayed, A. R. (1990): "The relationship between the hardness of treated water and cardiovascular disease mortality in South African urban areas". South African Med. J., 77:522-524.

IKem, A; Odueyungbo, S.; Egiebor, N. O. and Nyavor, K. (2002) : "Chemical quality of bottled waters from three cities in eastern Alabama". Sci. Total Environ., 285: 165-175.

Mohamed, M. A. and Osman, M. A. (1998): "Lead and cadmium in Nile river water and finished drinking water in

Mansoura J. Forensic Med. Clin. Toxicol.
Greater Cairo, Egypt". Environment International, 24: $767-772$.

Quinn, M. J. and Sherlock, J. C. (1990): "The correspondence between U.K. action levels for lead in blood and in water". Food Additives \& Contaminants, 7: 387424.

Saleh, M. A; Ewane, E.; Jones, J. and Wilson, B. (2001) : "Chemical evaluation of commercial bottled drinking water from Egypt". J. of Food Composition \& Analysis, $14: 127-152$.

Shayo, N. B.; Chove, B. E; Gidamis, A. B. and Ngoma, O. B. (2007) : "The quality of water in small community supplies of kingolwira village, Morogora, Tanzania". Tanzan Health Res. Bull. Jav., 9:56-60.

Tayyeb, Z. A; Farid, S. M. and Otaibi, K. A. (2004) : "Trace element concentration of commercially available drinking water in Makkah and Jeddah". JKAU Eng. Sci., 15: $149-154$.

USEPA (United States Environmental Protection Agency), (2004) : Drinking water standards and health advisories. EPA 822 - R- 04-005, Office of water, US Environmental Protection Agency, Washington D.C.

Virkutyte, J. and Sillanpaa, M. (2005): "Chemical evaluation of potable water in 
Eastern Qinghai Province, China: Human health aspects". Environment International, 32: 80- 86 .

WHO (2001) : Water health and human rights, World Water Day 2001.Available online at http://www. worldwaterday.org/themtic/ hmnrights. html n4.

WHO (2003a) : Lead in drinking water:Background document for development of WHO Guidelines for drinking water quality. World Health Organization, Geneva, Switzerland (WHO/ SDE/ WSH/ 03.04 / 09).

WHO (2003b) : Arsenic in drinking water. Background document for preparation of WHO Guidelines for drinking water quality. World Health Organization, Geneva, Switzerland (WHO/SDE/WSH) 03.04/75).

WHO (2003c) : Mercury in drinking water. Background document for preparation of WHO Guidelines for drinking water quality. World Health Organization, Geneva, Switzerland (WHO/SDE/WSH/ 03.04/10).

WHO (2003d): Selenium in drinking water. Background document for preparation of WHO Guidelines for drinking wa- ter quality. World Health Organization, Geneva, Switzerland (WHO/SDE/WSH/ 03.04/13).

WHO (2003e) : Hardness in drinking water. Background document for preparation of WHO Guidelines for drinking water quality. World Health Organization, Geneva, Switzerland (WHO/SDE/WSH/ $03.04 / 6)$.

WHO (2004a) : Guidelines for Drinking water quality, 3rd Ed., volume I: Recommendations, World Health Organization, Geneva, Switzerland.

WHO (2004b) : Cadmium in drinking water.Background document for development of WHO Guidelines for drinking water quality. World Health Organization, Geneva, Switzerland (WHO/SDE/WSH/ 03.04/80).

WHO (2006) : Guidelines for Drinking water quality.1st Addendum to the 3rd Ed., volume 1: Recommendations, World Health Organization, Geneva, Switzerland.

WHO (2007) : Chemical safty of drinking water: assessing priorities for risk management. World Health Organization, Geneva,Switzerland. 
الجو دة الكبهيائية لهياة الصنبور بالهقارنة بالهياه الهعبأة فيل زباجات :

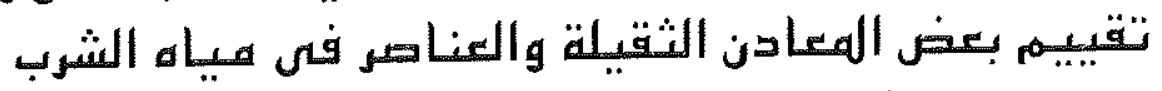
فنى هحافظة الدقهلية - هصر التئلة

$$
\text { المشتركون فى البحث }
$$

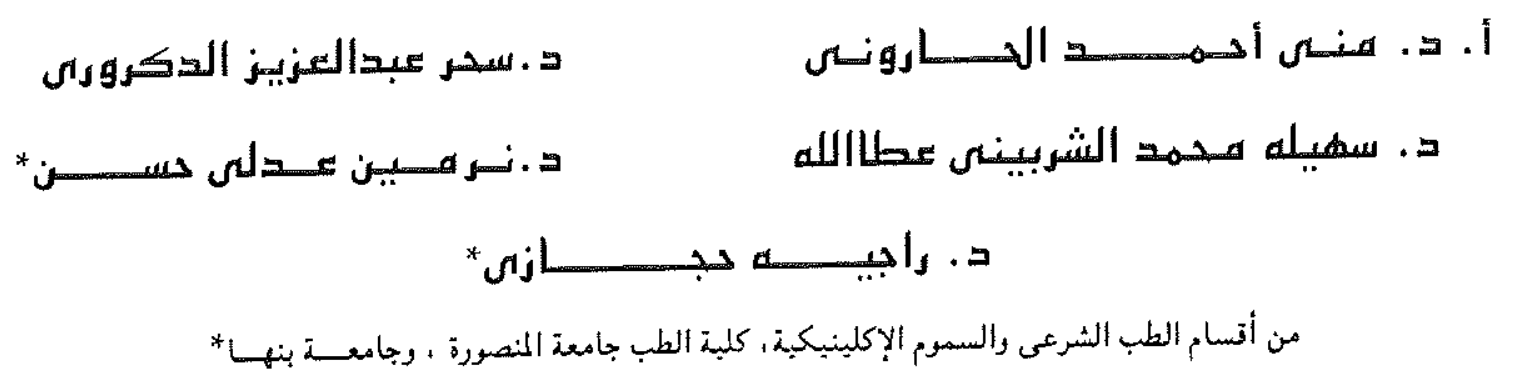

يعتبر الما، عاملل هـام لاستمرار المباة، ولابد أن يتوفر مصدر آمن للمستهلكين. . يوجد كثير من المواد الكبميائية المختلفة نى مياه

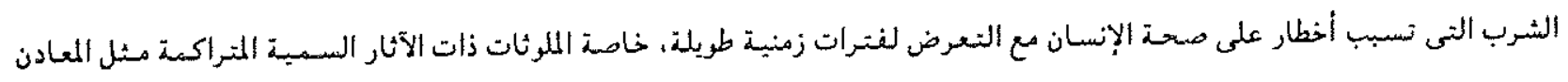
الثقبلة. هدذت هذه الدراسة إلى تقييم الجمودة الكيمبانية وأمان مباه الشرب (مباه الصنبور) في مهانظة الدتهلية، وتورنت بعينات من مياه الثرب المعبأة فى الزجاجات الشائعة تجارياً. أستخدم جهاز مقياس الطيف الجزينى لقياس عناصر الرصاص، الكادميوم، الزرنيخ، الزئبق، الزنك،

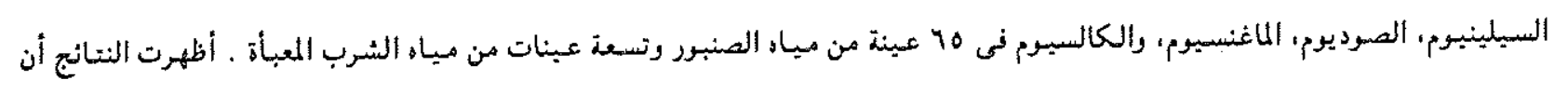

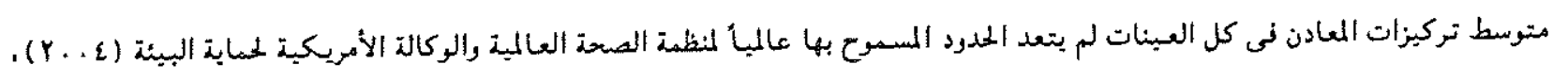
وأحتوت مياه الصنبور على تركيزات أعلى تليلاً لعناصر الرصاص، الزرنيخ، الكادمبوم ، الزنك، والسبلينيوم. 
